\title{
Policy related factors affecting the survival and development of SMEs in the context of Covid 19 pandemic
}

\author{
Hoang Ba Huyen Le ${ }^{a^{*}}$, Thi Loan Nguyen ${ }^{a}$, Chi Thanh Ngo ${ }^{a}$, Thi Bich Thu Pham ${ }^{a}$ and Thi Binh Le ${ }^{a}$
}

${ }^{a}$ Hong Duc University, Vietnam

\begin{tabular}{l}
\hline C H R O N I C L E \\
\hline Article history: \\
Received: March 18, 2020 \\
Received in revised format: \\
May 302020 \\
Accepted: June 17, 2020 \\
Available online: \\
June 18, 2020 \\
\hline Keywords: \\
Covid 19 \\
Economics \\
Enterprises \\
SMEs \\
Thanh Hoa province
\end{tabular}
A B S T R A C T

Based on the context of Thanh Hoa province, the research proposes the model of policy - related factors from the action of government (at all level) influencing on the survival and the development of SMEs. The research was conducted by collecting data from 512 SMEs in Thanh Hoa province. The results indicate that tax supporting policy and the preferential policies of the bank were crucial factors affecting the development of enterprises during the Covid 19 pandemic, directly. Other factors included insurance policy, capital support packages of Government, the act of public administration and the role of professional association which were considered as important elements affecting the enterprise's development. Based on the results, the study proposes policy implication in order to support SMEs overcome difficulties during the coronavirus pandemic.

Thanh Hoa province

C 2020 by the authors; licensee Growing Science, Canada

\section{Introduction}

Covid 19 pandemic has directly impact on enterprises (Sansa, 2020; Ruiz Estrada et al., 2020). In Vietnam, the Covid 19 pandemic has caused over $93 \%$ of enterprises in the country to be negatively impacted, leading to a serious decrease in revenue. The enterprises have also suffered the burden of stagnant inventory, interest rates, workers' wages and rental costs due to the Covid 19 pandemic (Tran, 2020). Thanh Hoa is the fifth largest province in the country and the third largest in terms of population. Thanh Hoa is a transitional province between the North and Central of Vietnam characterized by a diverse terrain with forests, plains and sea. It is the geographic and natural factors that are a great advantage for the local socio-economic development. In recent years, especially over the period 2015-2020, Thanh Hoa province has achieved outstanding achievements in socio-economic development. The province's economic growth has achieved positive results; the average growth rate of gross domestic product (GRDP) in the period is expected to reach $12.5 \%$.

From early December 2019 to the present, the world in general, including Vietnam, is facing the COVID-19 pandemic. The COVID-19 pandemic has been negatively affecting global and Vietnamese socio-economic activities. In particular, most industries and economic sectors were negatively affected. Based on such observation, we address the question of which are crucial factors increasingly the survival of SMEs in the context of Covid -19 pandemic. We construct the model with influence focus on: (i) Tax support policy; (ii) Preferential policies of the bank such as Policy on reducing bank interest rates and extending repayment period; (iii) Capital support packages of the Government; (iv) Insurance policy; (v) The action of public administration; (vi) The role of professional associations.

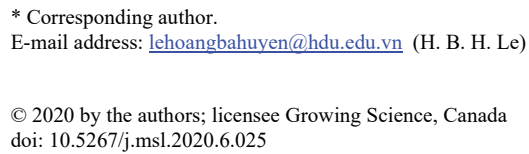




\section{Literature review}

Small and medium enterprises (SMEs): Although the term SMEs is used interchangeably worldwide, there is no common definition of these terms. The geographical placement of SMEs as well as country specific legislation influences the numerous SME definitions (Leopoulos, 2006). In Vietnam, the Decree 39/2018/ ND-CP guiding the Law on Supporting Small and Medium Enterprises has categorized SMEs into three categories namely micro enterprises, small enterprises and medium enterprises. The differentiating factor between these categories, excluding micro enterprises, is the number of employees, annual revenue and total assets. For micro enterprises, the criterion is turnover level.

Factors affecting survival and growth of SMEs: Salimzadeh et al. (2013) proposed the theoretical model of sustainable development of small and medium enterprises in Australia with two main groups of factors: internal and external factors where external factors affecting the development of small and medium-sized enterprises mainly coming from 3 parties: customers, government and stakeholders. Bouazza et al. (2015) performed an analysis of factors affecting the growth of SMEs in Algeria and showed a group of external factors including business environment, state policy, legal system, support policies of localities, customers and markets. These factors belong to the environment outside the enterprise, not being under the control of the enterprise, it constantly affects the entire business operation as well as the development of enterprises. In this study, the authors focus on assessing the impact of policies from government and related parties on the survival and growth of SMEs

Government policies: Even under normal economic conditions, governments have recognized that, in order to survive and grow, small and medium enterprises need specific policies and programs (OECD, 2009). The success of small and mediumsized enterprises is closely linked to local economic conditions because the market growth of small and medium-sized enterprises is often at the same level as that of the macro economy in general, so if the economic downturn, small and medium enterprises will also face difficulties (Berry et al., 2002). In the context of the 19th pandemic, small and medium enterprises have been facing a marked decline in demand for goods and services and production disruptions, thus preferential policies and programs of government should be conducted promptly. In a study conducted by the International Financial Corporation (IFC, 2003) based on the feedback of 45,000 enterprises in developing countries, it was found that leading factors hinder the development of enterprises including high tax, complicated law system, complex administrative procedures...All of the negative effects mentioned above are related to policies from the Government. The importance of SMEs to the economy of a country indicates how important it is to have government policies that support SMEs, including regulations that enable them to operate efficiently and regulations that reduce their administrative costs (Harvie and Lee, 2005). According to World Bank research, complex tax systems, low level of trust in the judicial system, and the need to pay bribes to access public services, represent major barriers for SMEs (WB, 2000). Lack of public sector support has a negative impact on entrepreneurship development in a country (Clover \& Darroch, 2005; Hoque \& Awang, 2019). Masurel (2007) argues that legislation and the desire to provide safe working conditions of government as the major motivating factors for SMEs to invest in improved sustainability performance. Therefore, it is possible that the government's policies on taxes, interest rates and social security play an important role in the survival and development of enterprises, especially small and medium enterprises in the context of the Covid 19 pandemic.

Polices of banks and financial instructions: SMEs in developing countries have difficulties in accessing bank loans as a consequence to the high risk for failing loans, low profitability and lack of collateral required by banks (Harvie \& Lee, 2005). In context of the Covid 19 pandemic, SMEs have faced difficulties in accessing finance to restore production, so the preferential policy of the bank on interest rates have a positive impact on survival and development of SMEs.

Support of professional association: In addition to supporting policies from local authority, the professional association also plays an important role for the development of SMEs. Programs implemented by the professional association such as organizing trade promotion activities, acting as a bridge among enterprises; between businesses and state management agencies. Thus, along with the support from the local government, the policy of professional association has shown a critical role in supporting the SMEs (Le, 20018)

\section{The context of Covid 19 pandemic and overview of small and medium enterprises in Thanh Hoa province}

\subsection{The context of Covid 19 pandemic}

The covid 19 epidemic is continuing to evolve globally, with the number of new cases and mortality increasing rapidly. The rapid and dangerous development of Covid 19 has led countries to apply a blockade in order to prevent the spread of Covid 19. That halted economic development and the flow of goods and services among countries and regions around the world. This reality has directly impacted on the existence and development of enterprises in all fields and throughout the regions (Tran, 2020). In Vietnam, the application of the social distancing order and the fear of epidemics have led to a sharp decline in consumer demand, production stagnation, and lack of raw materials for production which then making businesses face with many difficulties. According to the research results of National Economics University, many businesses are facing a decline in revenue $(60.2 \%)$ and $51.8 \%$ of enterprises operate under normal level. In addition, $43.4 \%$ of these businesses face difficulties due to lack of revenue; $39.4 \%$ could not carry out production and business activities; $31.2 \%$ of businesses could not be 
sold domestically; $17.20 \%$ of enterprises can not export their goods; $36.7 \%$ of enterprises suffer the shortage of capital, $29.1 \%$ of businesses are under the shortage of raw materials for production (National Economics University, 2020). The policy is one of the important factors affecting the existence and development of enterprises in the pandemic. Taxes, capital support packages, insurance policies, bank interest rates, the act of public administration as well as the role of professional associations are the direct influencing factors for enterprises to overcome and recover production and business in the context of the Covid 19 pandemic.

\subsection{Overview of small and medium enterprises in Thanh Hoa province}

In 2019, Thanh Hoa province has established 3,200 new businesses, ranking the $7^{\text {th }}$ in the country in term of the number of newly established businesses. This brings the total number of registered enterprises to 23,500 enterprises, in which nearly 15,500 enterprises are active. These enterprises contribute to $70 \%$ of the provincial GRDP. In term of structure, small and medium-sized enterprises (SMEs) account for 98.03\%, annually contributing 35-45\% of GRDP throughout the province and creating over $60 \%$ of total employment. SMEs in Thanh Hoa province are being considered as a main force to promote and develop large enterprises in Thanh Hoa (Do, 2019). Of the total number of SMEs, small and micro enterprises account for nearly $98 \%$. The percentage of small businesses in Thanh Hoa province is $10 \%$ larger in comparison to the national level (nationwide $87 \%$ ). Although SMEs accounts for $98 \%$ in term of number, SMEs only account for about $50 \%$ in term of capital (Thanh Hoa Statistical Office, 2019). In terms of business structure of SMEs, commercial and service enterprises account for the largest proportion (over 30\%), followed by construction, agricultural processing and transportation enterprises, accounts for more than 50\% ((Thanh Hoa Statistical Office, 2019)

\section{Research methodology}

It is largely considered that Covid 19 has directly impact on enterprises (Sansa, 2020; Ruiz Estrada, Koutronas \& Lee, 2020). From that point of view, the authors propose the research model based on theoretical model of sustainable development of small and medium enterprises by Salimzadeh et al. (2013). In which, the model focuses on roles of governments and related parties as an external factor in the survival and growth of SMEs. Based on the research overview presented, it can be seen that the policies of the government and stakeholders have an influence on the survival and growth of SMEs, so the study proposes the following hypotheses:

H1: Tax supporting policy has a positive influence on the survival and development of SMEs in Thanh Hoa province.

H2: Preferential policies of the bank has a positive influence on the survival and development of SMEs in Thanh Hoa province.

H3: Capital support packages of the Government has a positive influence on the survival and development of SMEs in Thanh Hoa province.

H4: Insurance policy has a positive influence on the survival and development of SMEs in Thanh Hoa province.

H5: The act of public administration has a positive influence on the survival and development of SMEs in Thanh Hoa province.

H6: The role of professional association has a positive influence on the survival and development of SMEs in Thanh Hoa province.

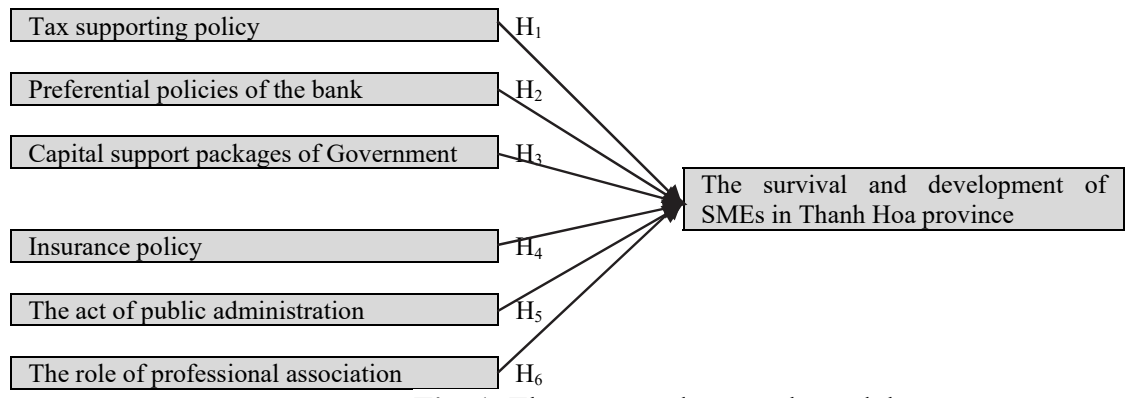

Fig. 1. The proposed research model

\subsection{Data description}

\subsubsection{Survey description}

The authors have used a random quantitative survey method which was conducted from April 10 to April 23, 2020 in Thanh Hoa province. Before sending questionnaires to the enterprises, the author group sent a preliminary questionnaire to 20 experts including managers and experts in business to assess the reliability of the scales, and to adjust the questionnaires accordingly before conducting a broad survey. After receiving the questionnaires, the team conducted the cleaning of the information, filtered, encoded the necessary information in the questionnaire, entered data and analyzed the data with SPSS software version 20.0. Quantitative research methods are used mainly in research such as Cronbach's alpha reliability test, exploratory factor analysis (EFA), regression analysis. 
Sample size: According Hair et al. (1998), for exploratory factor analysis (EFA), the minimum sample size $\mathrm{N} \geq 5 \times \mathrm{x}$ (x: total number of observed variables). The research consists of 28 observation variables; therefore, the minimum sample size needed is $28 \times 5=140$ observations. For multiple regressions, according to Tabachnick and Fidell, the minimum sample size is given by the formula: $50+\mathrm{m} \times 3=50+6 \times 3=68$ ( $\mathrm{m}$ is the independent variable). Thus, to compile these two requirements, the minimum sample size for this research is 140 observations. From April 10 to April 23, 2020, the authors have collected 512 questionnaires using Google docs' tool (https://forms.gle/oAysjyG6DWivVkLT8), phone interviews, skype, zalo and facebook. The sample is summarized as follows:

Table 2

Descriptive statistics of the sample

\begin{tabular}{|c|c|c|c|}
\hline $\begin{array}{c}\text { Criteria } \\
\text { Number of employees }\end{array}$ & Percentage & $\begin{array}{l}\text { Criteria } \\
\text { Capital } \\
\end{array}$ & Percentage \\
\hline Less than 20 employees & $66.8 \%$ & Below 1 billion dong & $9.0 \%$ \\
\hline From 20 to 49 employees & $18.3 \%$ & From 1 to 10 billion dong & $71.5 \%$ \\
\hline From 50 to 99 employees & $5.1 \%$ & From 10 to 50 billion dong & $13.3 \%$ \\
\hline From 100 to 199 employees & $4.3 \%$ & From 50 to 10 billion dong & $2.3 \%$ \\
\hline More than 200 employees & $5.5 \%$ & Over 10 billion dong & $3.9 \%$ \\
\hline Scope of activities & & Annual revenue & \\
\hline Trading and services & $55.0 \%$ & Below 10 billon dong & $12.0 \%$ \\
\hline Agriculture & $1.0 \%$ & From 10 to 50 billion dong & $38.0 \%$ \\
\hline Construction & $19.0 \%$ & From 50 to 100 billion dong & $36.0 \%$ \\
\hline Manufacture & $14.5 \%$ & From 100 to 200 billion dong & $9.0 \%$ \\
\hline Travel & $3.0 \%$ & Over 200 & $5.0 \%$ \\
\hline Education & $3.0 \%$ & Annual profit & \\
\hline Other & $4.5 \%$ & Profit over 10 billion dong & $3.5 \%$ \\
\hline Type of business & & Profit from 1 to 10 billion dong & $12.1 \%$ \\
\hline Limited company (1 member) & $21.1 \%$ & Profit below 1 billion dong & $47.3 \%$ \\
\hline Limited company ( from 2 member) & $51.2 \%$ & Breakeven & $19.5 \%$ \\
\hline Joint stock company & $19.1 \%$ & Loss below 5 billion dong & $17.6 \%$ \\
\hline Private company & $5.9 \%$ & Loss over 5 billion dong & $0.0 \%$ \\
\hline Other & $2.7 \%$ & & \\
\hline
\end{tabular}

(Source: Survey and statistics results, April 2020)

Of 512 enterprises surveyed, in term of number of employees, $66.8 \%$ of enterprises have less than 20 workers, accounting for the largest proportion. The research results of 512 enterprises in the province are allocated by scope of activities: $55 \%$ are commercial and service enterprises, $19 \%$ construction enterprises; $14.5 \%$ of manufacturing enterprises, education and tourism enterprises account for 3\%, and the others are agricultural enterprises, leather shoes businesses...In term of type of business, $51.2 \%$ of businesses are limited companies. About capital, 71.5\% of companies have the total capital from 1 to 10 billion dong. Of annual revenue, $38 \%$ of enterprises have the annual revenue from 10 to 50 billion dong and $36 \%$ have from 50 to 100 billion dong of the annual revenue. In term of annual profit, $47.3 \%$ of businesses have the annual profit below 1 billon dong, accounting for majority.

\subsubsection{Measure Scale and variables}

Table 2

Description of observational variables within the groups of influencing factors

\begin{tabular}{|c|c|c|}
\hline Factors & Observational variables & $\begin{array}{c}\text { Variable } \\
\text { codes }\end{array}$ \\
\hline \multirow{5}{*}{ Tax supporting policy $\left(\mathbf{X}_{1}\right)$} & Policy on tax exemption and reduction (CIT, VAT, PIT ...) & TP.1 \\
\hline & Tax payment extension & TP.2 \\
\hline & Exempted from late tax payment & ТР.3 \\
\hline & No tax inspections are conducted & TP.4 \\
\hline & Extension of land rental payment & TP.5 \\
\hline \multirow{5}{*}{$\begin{array}{l}\text { Preferential policies of the bank } \\
\qquad\left(\mathrm{X}_{2}\right)\end{array}$} & Shorten processing time for loan applications & BP.1 \\
\hline & Reduce interest rates on new loans & BP. 2 \\
\hline & Exemption and reduction of loan interests & BP. 3 \\
\hline & Debt rescheduling & BP.4 \\
\hline & Exemption and reduction of fees & BP.5 \\
\hline $\begin{array}{l}\text { Capital support packages of the } \\
\text { Government }\left(\mathrm{X}_{3}\right)\end{array}$ & Support for employers to pay work stoppage wages for employees & CSP 1 \\
\hline
\end{tabular}




\begin{tabular}{|c|c|c|}
\hline Factors & Observational variables & $\begin{array}{l}\text { Variable } \\
\text { codes }\end{array}$ \\
\hline & $\begin{array}{l}\text { Cash support for workers with reduced income, job losses and un- } \\
\text { employment ... }\end{array}$ & CSP 2 \\
\hline & Support individual business households suspended business & CSP 3 \\
\hline & $\begin{array}{l}\text { Capital support of allowances for participating forces (of enterprises) } \\
\text { against COVID-19 epidemic prevention }\end{array}$ & CSP 4 \\
\hline \multirow{3}{*}{ Insurance policy $\left(\mathrm{X}_{4}\right)$} & $\begin{array}{l}\text { Suspension of payment of social insurance premiums (pension and } \\
\text { survivorship fund) }\end{array}$ & IP 1 \\
\hline & Exemption of unemployment insurance premium & IP 2 \\
\hline & $\begin{array}{l}\text { No inspections of compliance with laws on social insurance, health } \\
\text { insurance and unemployment insurance are conducted }\end{array}$ & IP 3 \\
\hline \multirow{4}{*}{$\begin{array}{l}\text { Action of Public Administration } \\
\qquad\left(\mathrm{X}_{5}\right)\end{array}$} & The administrative procedures are simplified & AP 1 \\
\hline & Responsible staff, enthusiastic support & AP 2 \\
\hline & Application of information technology in management & AP 3 \\
\hline & The procedures and records are clearly and transparently prescribed & AP 4 \\
\hline \multirow{4}{*}{$\begin{array}{l}\text { The Role of Professional } \\
\text { Association }\left(\mathbf{X}_{6}\right)\end{array}$} & $\begin{array}{l}\text { The Association brings together recommendations and proposals } \\
\text { from businesses to the Government and local authorities }\end{array}$ & PA 1 \\
\hline & The Association promotes trade promotion & PA 2 \\
\hline & The Association acts as a bridge to connect business cooperation & PA 3 \\
\hline & The Association supports businesses production recovery & PA 4 \\
\hline \multirow{3}{*}{$\begin{array}{l}\text { Survival and development of } \\
\text { SMEs (Y) }\end{array}$} & Enterprises are recovering production & SD 1 \\
\hline & Enterprises are maintaining production & SD 2 \\
\hline & Enterprises are gradually developing & SD 3 \\
\hline
\end{tabular}

\section{The results and conclusion}

The results of reliability testing conducted by SPSS.20 software indicate that 2 variables including BP1- Shorten processing time for loan applications and TP4- No tax inspections are eliminated because the Corrected Item-total correlation coefficient is less than 0.3 . The results of processing the remaining variables ( 23 independent observation variables and 3 dependent observation variables) are shown in Table 3:

Table 3

The results of the second reliability testing

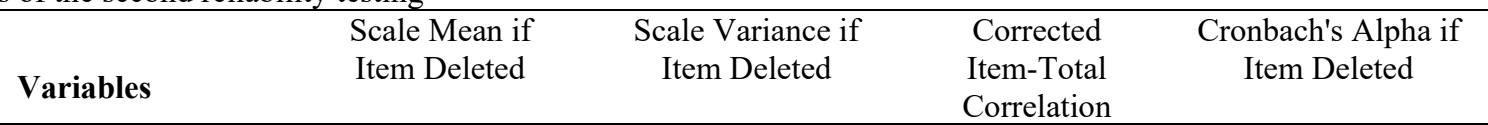

\begin{tabular}{|c|c|c|c|c|}
\hline \multirow{2}{*}{ Tax supporting policy } & \multirow{2}{*}{\multicolumn{4}{|c|}{ Alpha $=\mathbf{0 . 8 7 7}$}} \\
\hline & & & & \\
\hline TP1 & 11.17 & 6.966 & .629 & .871 \\
\hline TP2 & 11.03 & 5.578 & .836 & .800 \\
\hline TP3 & 10.75 & 6.480 & .764 & .833 \\
\hline TP5 & 11.04 & 6.112 & .724 & .847 \\
\hline $\begin{array}{l}\text { Preferential policies of the } \\
\text { bank }\end{array}$ & \multicolumn{4}{|c|}{ Alpha $=0.910$} \\
\hline BP2 & 11.09 & 5.909 & .768 & .894 \\
\hline BP3 & 11.13 & 6.089 & .745 & .902 \\
\hline BP4 & 11.19 & 5.694 & .850 & .865 \\
\hline BP5 & 11.17 & 6.007 & .828 & .874 \\
\hline $\begin{array}{c}\text { Capital support packages of } \\
\text { the Government }\end{array}$ & \multicolumn{4}{|c|}{ Alpha $=0.851$} \\
\hline CSP1 & 10.94 & 5.939 & .654 & .825 \\
\hline CSP2 & 10.95 & 5.136 & .788 & .766 \\
\hline CSP3 & 10.79 & 5.738 & .726 & .796 \\
\hline CSP4 & 10.83 & 6.084 & .601 & .847 \\
\hline Insurance policy & \multicolumn{4}{|c|}{ Alpha $=0.846$} \\
\hline IP1 & 7.09 & 2.845 & .688 & .811 \\
\hline IP2 & 7.29 & 2.159 & .777 & .726 \\
\hline IP3 & 6.84 & 2.781 & .693 & .805 \\
\hline
\end{tabular}




\begin{tabular}{|c|c|c|c|c|}
\hline $\begin{array}{l}\text { Action of Public Admin- } \\
\text { istration }\end{array}$ & \multicolumn{4}{|c|}{ Alpha $=0.857$} \\
\hline PA1 & 11.26 & 6.077 & .694 & .822 \\
\hline PA2 & 11.30 & 5.172 & .762 & .791 \\
\hline PA3 & 11.15 & 5.670 & .762 & .793 \\
\hline PA4 & 11.29 & 5.876 & .601 & .850 \\
\hline $\begin{array}{c}\text { The Role of Professional } \\
\text { Association }\end{array}$ & \multicolumn{4}{|c|}{ Alpha $=0.879$} \\
\hline AP1 & 11.21 & 5.029 & .715 & .854 \\
\hline AP2 & 11.28 & 5.184 & .663 & .875 \\
\hline AP3 & 11.28 & 5.002 & .799 & .821 \\
\hline AP4 & 11.20 & 5.218 & .786 & .828 \\
\hline $\begin{array}{l}\text { Survival and development } \\
\text { of SMEs }\end{array}$ & \multicolumn{4}{|c|}{ Alpha $=0.872$} \\
\hline SD1 & 7.30 & 3.004 & .762 & .814 \\
\hline SD2 & 7.13 & 2.768 & .796 & .785 \\
\hline SD3 & 6.92 & 3.714 & .735 & .850 \\
\hline
\end{tabular}

The remaining observed variables all have Cronbach's Alpha coefficient greater than 0.6 and the corrected item -total correlation coefficients of variables are more than 0.3 (Nunnally \& Bernstein, 1994). Therefore, these measurement variables are reliable and are used in EFA.

\section{Exploratory factor analysis of independent variables}

Factor analysis is used for a multidirectional scale to identify components or factors that explain the correlation in a variable set. Exploratory factor analysis is appropriate when KMO (Kaiser-Mayer-Olkin) coefficient has a value from 0.5 to 1 , and the significance of the Bartlett's test of sphericity has to be less than 0.05 (Hoang \& Chu, 2008; Imran et al., 2018). The factor analysis method applied in the research is Principal Components with Varimax rotation. The results in table 4 have shown the $\mathrm{KMO}=0.829(0.5<=\mathrm{KMO}<=1)$; Bartlett's Test statistic $=7688.416$ with $\mathrm{Sig}=0.00<0.05$; this means that the application of exploratory factor analysis in the study is appropriate.

Table 4

KMO and Bartlett's Test of Sphericity

Kaiser-Meyer-Olkin Measure of Sampling Adequacy.

Approx. Chi-Square

7688.416

Bartlett's Test of Sphericity

df

Moreover, Table 5 indicates that all factors have the eigenvalue $>1$ which explains is greater than $50 \%(61.449 \%)$. Thus, exploratory factor analysis used in this case is statistically significant.

Table 5

Rotated Component Matrix

\begin{tabular}{lccccc}
\hline & \multicolumn{5}{c}{ Component } \\
\cline { 2 - 5 } & 1 & 2 & 3 & 4 & 5 \\
\hline BP4 & .895 & & & \\
BP5 & .885 & & & \\
BP2 & .799 & & & \\
BP3 & .767 & & & \\
AP2 & & .896 & & \\
AP4 & & .846 & & \\
AP3 & & .843 & & \\
AP1 & & .753 & & \\
TP3 & & & & \\
TP5 & & & .808 & \\
TP1 & & & .7897 \\
TP2 & & & & \\
\hline
\end{tabular}




\begin{tabular}{|c|c|c|c|c|c|c|}
\hline CSP2 & & & & .826 & & \\
\hline CSP1 & & & & .810 & & \\
\hline CSP3 & & & & .803 & & \\
\hline CSP4 & & & & .705 & & \\
\hline PA2 & & & & & .845 & \\
\hline PA3 & & & & & .807 & \\
\hline PA1 & & & & & .729 & \\
\hline PA4 & & & & & .717 & \\
\hline IP2 & & & & & & .893 \\
\hline IP1 & & & & & & .819 \\
\hline IP3 & & & & & & .800 \\
\hline Eigenvalue & 7.088 & 2.876 & 2.441 & 1.898 & 1.589 & 1.239 \\
\hline Cumulative $\%$ & 30.817 & 43.321 & 53.934 & 62.185 & 69.095 & 74.482 \\
\hline
\end{tabular}

The rotated component matrix presented in Table 5 shows 23 independent observation variables (after eliminating 2 independent observation variables BP1 and TP4 from Cronbach's alpha test results) are divided into 6 groups of factors. All factor loadings are greater than 0.5 , ensuring the distinction between load factors greater than 0,3 ; and the variables retained exactly as the groups in the original scale (Table 5). To assess the influence of each element on the survival and development of SMEs in the context of Covid-19 pandemic, the authors used a multivariate regression model. After using SPSS.20 software, the results are as follows:

Table 6

Model Summary Model R Square Adjusted R Square Std. Error of the Estimate Durbin-Watson

The analysis of Table 6 indicates that the model has $\mathrm{R} 2=0.754$ and adjusted $\mathrm{R} 2=0.749$. This means $74.9 \%$ of the variation of the dependent factor "The survival and development of SMEs" is explained by 6 factors: Tax supporting policy (TP); preferential policies of the bank (BP); Capital support packages of the Government (CSP); Insurance policy (IP); Action of Public Administration (AP) and The Role of Professional Association (PA). Besides, the Durbin-Watson coefficient $=1,513(>1)$ indicates that there is no self-correlation between variables.

Table 7

ANOVA $^{\mathrm{a}}$

\begin{tabular}{rrrrrrr}
\hline & Model & Sum of Squares & df & Mean Square & F & Sig. \\
\hline \multirow{2}{*}{1} & Regression & 96.186 & 6 & 16.031 & 28.563 & $.000^{\mathrm{b}}$ \\
& Residual & 283.429 & 505 & .561 & & \\
& Total & 379.614 & 511 & & & \\
\hline
\end{tabular}

The $\mathrm{F}$ test has been used in the analysis of variance to test the hypothesis of the suitability of the regression model. With significance level sig $=0.000<0.05$, which shows that the combination of factors in the model can explain the change of the dependent factor. The Kolmogorov-Smirnov test, with sig. $=0.2$ (greater than 0.05 ) indicates that the residual distribution is accepted as the normal distribution. Besides, by observing the dispersion of observation points around the expected straight line, we find that the residual distribution completely coincides with a standard distribution. Therefore, it is possible to conclude that the residuals are normally distributed (Figure 3).
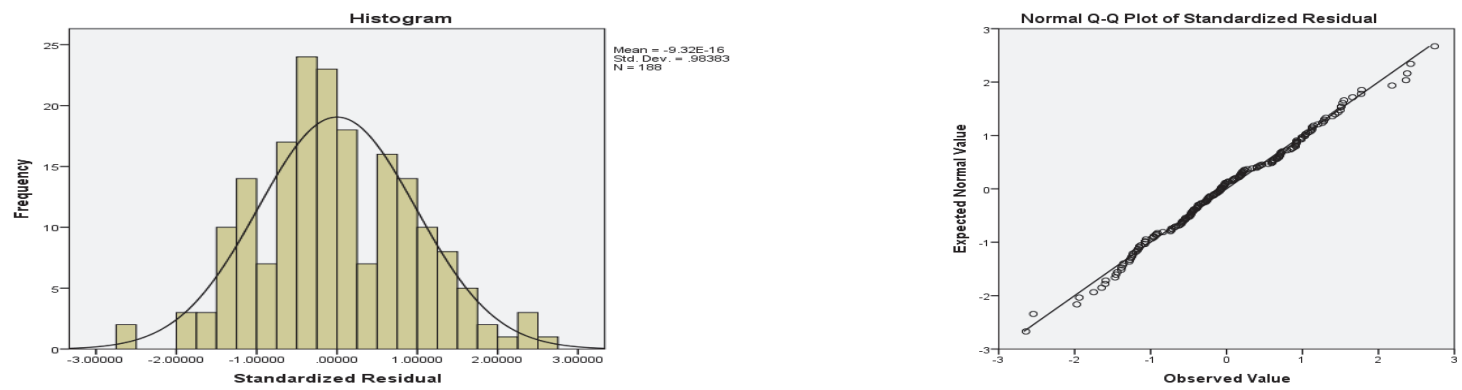

Fig. 3. Histogram of Standardized residual 
Moreover, the one - sample test on residuals gives the value of sig. $=1$, showing that the average of the residuals $=0$. The Pearson's correlation coefficient between residual and independent variable shows $\operatorname{sig}=1$; this means there is no correlation between the residual and the independent variables. The heterogeneous variance assumption is satisfied.

The results of multiple regression analysis are as follows:

Table 8

The results of multiple regression

\begin{tabular}{|c|c|c|c|c|c|c|c|c|}
\hline & \multirow[t]{2}{*}{ Model } & \multicolumn{2}{|c|}{ Unstandardized Coefficients } & \multirow{2}{*}{$\begin{array}{c}\begin{array}{c}\text { Standardized } \\
\text { Coefficients }\end{array} \\
\text { Beta } \\
\end{array}$} & \multirow[t]{2}{*}{ t } & \multirow[t]{2}{*}{ Sig. } & \multicolumn{2}{|c|}{ Collinearity Statistics } \\
\hline \multirow{8}{*}{1} & & $\mathrm{~B}$ & Std. Error & & & & Tolerance & VIF \\
\hline & (Constant) & -1.485 & .190 & & -7.835 & .000 & & \\
\hline & $\mathrm{TP}$ & .261 & .041 & .243 & 6.308 & .000 & .601 & 1.664 \\
\hline & $\mathrm{BP}$ & .360 & .042 & .301 & 8.634 & .000 & .732 & 1.366 \\
\hline & CSP & .271 & .040 & .247 & 6.757 & .000 & .668 & 1.498 \\
\hline & IP & .242 & .041 & .236 & 5.871 & .000 & .552 & 1.813 \\
\hline & AP & .127 & .028 & .139 & 4.538 & .000 & .948 & 1.055 \\
\hline & PA & .161 & .040 & .157 & 4.034 & .000 & .591 & 1.691 \\
\hline
\end{tabular}

The results of Table 8 show that all independent variables have sig $<0.05$, meaning that all independent factors influence the dependent factor "The survival and development of SMEs". The importance of each factor depends on the standardized Beta factor (in terms of the absolute value of the coefficient), or any factor with a large standardized Beta factor that has a strong impact on The survival and development of SMEs. We have the following regression equation:

$$
\mathrm{SD}=-1.485+0.243 \mathrm{TP}+0.301 \mathrm{BP}+0.247 \mathrm{CSP}+0.236 \mathrm{IP}+0.139 \mathrm{AP}+0.157 \mathrm{PA}
$$

In which: The survival and development of SMES (SD); Tax supporting policy (TP); Preferential policies of the bank (BP); Capital support packages of the Government (CSP); Insurance policy (IP); Action of Public Administration (AP) and The Role of Professional Association (PA). Based on the results of the regression equation, it shows that the variable Preferential policies of the bank most strongly affects The survival and development of SMEs (standardized coefficient $\beta=0.301$ ). This means, when Preferential policies of the bank increased by 1 unit, The survival and development of SMEs increased by 0.301 units. Similarly, the second most powerful factor affecting The survival and development of SMEs is Capital support packages of the Government (standardized coefficient $\beta=0.247$ ), followed by factors: Tax supporting policy (standardized coefficient $\beta=0.243$ ); Insurance policy (standardized coefficient $\beta=0.236$ ); The Role of Professional Association (standardized coefficient $\beta=0.157$ ) and Action of Public Administration (standardized coefficient $\beta=0.139$ ) both have positive effects on The survival and development of SMEs. Therefore, the hypotheses of study H1, H2, H3, H4, H5, H6 are accepted. From the research results, we have the results of testing the proposed research hypotheses as follows:

Table 9

The results of testing the proposed research hypotheses

\section{Hypotheses}

Results

\begin{tabular}{llc} 
& & variable \\
\hline $\begin{array}{l}\text { H1: Tax supporting policy has a positive affected to the Survival and Development } \\
\text { of SMEs in Thanh Hoa province }\end{array}$ & Accepted \\
H2: Preferential policies of the bank has a positive affected to the Survival and \\
$\begin{array}{l}\text { Development of SMEs in Thanh Hoa province } \\
\text { H3: Capital support packages of the Government has a positive affected to the Sur- } \\
\text { vival and Development of SMEs in Thanh Hoa province }\end{array}$ & Accepted \\
$\begin{array}{l}\text { H4: Insurance policy has a positive affected to the Survival and Development of } \\
\text { SMEs in Thanh Hoa province }\end{array}$ & Accepted \\
$\begin{array}{l}\text { H5: } \text { The act of public administration has a positive affected to the Survival and } \\
\text { Development of SMEs in Thanh Hoa province }\end{array}$ & Accepted \\
$\begin{array}{l}\text { H6: The role of professional Association has a positive affected to the Survival and } \\
\text { Development of SMEs in Thanh Hoa province }\end{array}$ & Accepted & 6 \\
\hline
\end{tabular}

\section{Recommendation}

5.1. Issue policies to reduce bank interest rates and extend the repayment period for businesses: this is one of the important solutions to help businesses overcome the pandemic, especially for SMEs with small scale, limited capital and limited market share. Exemptions and reductions of interests and fees shall be made for outstanding loans arising from credit activities for 
which the principal and/or interest is paid during the period from January 23, 2020 to the next day after 03 months as from the day the Prime Minister announced the end of the Covid-19 epidemic, and customers were unable to pay the debt principal and / or interest in due time due to a decrease in revenue and income from the Covid-19 epidemic.

5.2. Promptly deploy support packages to stabilize and recover production: timely support packages will create favorable conditions for enterprises to maintain production and business activities in the context of the market being seized due to disruptions in production chains. In this context, if there is timely support in terms of credit and capital, businesses will ensure stable production scale, ensure production activities and provide enough employment for workers.

5.3. Proposal for tax exemption, reduction of taxes, fees and charges for businesses: The reduction of tax collection, or some fees and charges will contribute to reducing costs for businesses. Exemption and reduction of fees and charges shows the sharing between the state, the people and businesses in the context of the pandemic. This might lead the decrease of the state budget in short term, however for the long term more taxes are collected and more jobs are created as enterprises rehabilitate.

5.4. Suspend the payment of retirement and death insurance fund: In the immediate future, the policy should focus on two specific groups: (1) employees who have to stopped from work or quit their jobs due to the COVID -19 pandemic: (2) enterprises affected by COVID-19 with more than $50 \%$ of employees having to laid off, take time off or being damaged over $50 \%$ of total value due to the COVID -19 pandemic. In addition, state agencies should not conduct specialized inspection or compliance with social insurance, health insurance and unemployment insurance laws during the covid-19 pandemic.

5.5. Strengthen supply and demand linkage, promote trade and promote cooperation among enterprises through the role of professional associations: In the difficult period under the impact of Covid-19 epidemic, the cooperation among enterprises in same industries or in production chains can be one of the important ways to help businesses overcome the epidemic. In addition, the role of professional associations should be strengthened to make stronger bridge with state agencies and promote trade promotion for supporting businesses recovery after the epidemic.

5.6. Improve the proficiency of staff in the state administrative system: The research results show that the operational efficiency of the state administrative system plays an important role to support businesses to overcome the Covid 19 pandemic. Moreover, simplifying the procedures also help business facilitate their operations. In addition, the administrative agencies also need to postpone, stop and extend the time for examinations and inspections to create favorable conditions for enterprises to recover after the Covid 19 pandemic.

\section{References}

Berry, A., von Blottnitz, M., Cassim, R., Kesper, A., Rajaratnam, B., \& van Seventer, D. E. (2002). The economics of SMMES in South Africa. Trade and Industrial Policy Strategies, 1(1), 1-110.

Bouazza, A. M. (2015). Establishing the Factors Affecting the Growth of Small and Medium-sized Enterprises in Algeria. American International Journal of Social Science, 4 (2), 101 - 115.

Darroch, M. A., \& Clover, T. A. (2005). The effects of entrepreneurial quality on the success of small, medium and micro agribusinesses in KwaZulu-Natal, South Africa. Agrekon, 44(3), 321-343.

Do, D.H. (2019). Report on the development of SMEs in Thanh Hoa. Thanh Hoa Business Association, Thanh Hoa. Vietnam.

Divakara, S., Semasinghe, D. M., \& Surangi, H. A. K. N. S. (2019). A Literature review on Intrapreneurial constraints in the development of Small and Medium scale Enterprises. International Journal of Current Research, 11(11), 8540-8547.

Hair, J.F., Black, W.C., Babin, B.J., Anerson, R.E. \& Tatham, R.L. (1998), Multivariate data analysis, 5 (3), $207-219$.

Harvie, C. \& Lee, B. C. (2005). Introduction: the role of small and medium-sized enterprises in achieving and sustaining growth and performance. In C. Harvie \& B. C. Lee (Eds.), Sustaining Growth and Performance in East Asia The Role of Small and Medium Sized Enterprises (pp. 3-27). Cheltenham, UK: Edward Elgar Publishing.

Hoang,T., \& Chu, N.M.N. (2008), Analyze research data with SPSS (Volume 1 and 2). Ha Noi, Viet Nam: Hong Duc publishing.

Hoque, A. S. M. M., \& Awang, Z. (2019). Does gender difference play moderating role in the relationship between entrepreneurial marketing and Bangladeshi SME performance?. Accounting, 5(1), 35-52.

Imran, M., Aziz, A., Hamid, S., Shabbir, M., Salman, R., \& Jian, Z. (2018). The mediating role of total quality management between entrepreneurial orientation and SMEs export performance. Management Science Letters, 8(6), 519-532.

International Financial Corporation (2003). Sustainability Review. Retrieved 5 ${ }^{\text {th }}$ April, 2020 from https://www.ifc.org/wps/wcm/connect/56e4a869-08e4-4651-992e-3e0ff6d17cbd/AR2003 English ExeSum.pdf?MOD=AJPERES\&CVID=i.GLm2N

Le, N.N.(2018). Factors affecting development of industry SMEs in Thai Nguyen province. Doctoral thesis. Thai Nguyen university. Vietnam

Leopoulos V (2006). Editorial. Production Planning Control, 17(3), 225-228.

Masurel, E. (2007). Why SMEs invest in environmental measures: sustainability evidence from small and medium-sized printing firms. Business Strategy and the Environment, 16, 190-201. 
Ministry of Planning and Investment. (2019). The white book - Vietnamese business in 2019. Ha Noi, Vietnam: Statistics Publishing

Nunnally, J. \& Berstein, I.H. (1994), Pschychometric Theory, 3rd ed., New York: McGraw-Hill.

National Economics University. (2020). The report assesses the impact of Covid 19 on the economy and policy recommendations. Ha Noi. Viet Nam. Retrieved 10 ${ }^{\text {th }}$ April, 2020 from http://trungtamwto.vn/download/19344/bao-cao-danh-gia-tacdong-covid-19-den-nen-kinh-te.pdf

OECD (2009). The Impact of the Global Crisis on SME and Entrepreneurship Financing and Policy Responses. Retrieved $5^{\text {th }}$ April, 2020 from http://www.oecd.org/industry/smes/49316499.pdf

Salimzadeh, P., Courvisanos, J., \& Raveendranath, R. N. (2013). Sustainability in Small and Medium Sized Enterprises in Regional Australia: A Framework of Analysis.26 ${ }^{\text {th }}$ Annual SEAANZ Conference Proceedings.

Ruiz Estrada, M. A., Koutronas, E., \& Lee, M. (2020). Stagpression: The economic and financial impact of Covid-19 Pandemic. Available at SSRN 3578436.

Sansa, N. A. (2020). The Impact of the COVID-19 on the Financial Markets: Evidence from China and USA. Available at SSRN 3562530.

Smit, Y., \& Watkins, J. A. (2012). A literature review of small and medium enterprises (SME) risk management practices in South Africa. African Journal of Business Management, 6(21), 6324.

Tabachnick, B. G., \& Fidell, L. S. (2007). Using Multivariate Statistics (5th ed.). New York: Allyn and Bacon.

Tran, T.D. (2020), The impact of the COVID-19 pandemic on the Vietnamese economy and coping solutions, Journal of Economics and Development, 274, 14-22

World Bank - Europe and Central Asia region, International Monetary Fund (2000) The Road to Stability and Prosperity in South Eastern Europe: A Regional Strategy Paper

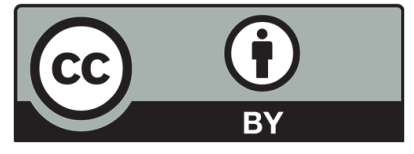

(C) 2020 by the authors; licensee Growing Science, Canada. This is an open access article distributed under the terms and conditions of the Creative Commons Attribution (CC-BY) license (http://creativecommons.org/licenses/by/4.0/). 